\title{
A new species of bristletail of the genus Allopsontus (Microcoryphia: Machilidae) from Dagestan (Russia)
}

\author{
Новый вид щетинохвосток рода Allopsontus \\ (Microcoryphia: Machilidae) из Аагестана (Россия)
}

\author{
Vladimir G. Kaplin \\ ВАадимир Г. Каплин
}

All-Russian Institute of Plant Protection, St. Petersburg, Pushkin 196608 Russia. E-mail: ctenolepisma@mail.ru. Всероссийский НИИ защиты растений, Санкт-Петербург, Пушкин 196608, Россия.

KEY WORDS: Western Palaearctic, Great Caucasus, Agvali, Machilinae, Allopsontus, new species.

КЛЮЧЕВЫЕ СЛОВА: Западная Палеарктика, Большой Кавказ, Агвали, Machilinae, Allopsontus, новый вид.

ABSTRACT: A new species of bristletail, i.e. Allopsontus agvalensis sp.n., is described and illustrated on material from the Eastern Caucasus. This species is characterized by the presence of $2+2$ exsertile vesicles on urocoxites II-V and the absence of long thin chaetae on legs, maxillary and labial palpi of the male and belongs to the nominotypical subgenus Allopsontus s. str. Among described species of this subgenus $A$. agvalensis sp.n. can be compared with two congeners, $A$. verae Kaplin, 2015 and A. hebraeus (Wygodzinsky, 1974), whose males also possess numerous small chaetae on the ventral surfaces of palpomeres 5-7 of the maxillary palp as well as on apical palpomere 3 of the labial palp and a narrow sensory field on fore femur. The new species differs from both $A$. verae and $A$. hebraeus in eye color, short contact line of eyes, the small number of ramose sensilla on the fore femur in males, the longer apical palpomere of the maxillary palp and shorter urostyli of urocoxites IX.

РЕЗЮМЕ: Allopsontus agvalensis sp.n., с двумя парами выпячивающихся мешочков на II-V брюшных кокситах и без длинных тонких щетинок на ногах, нижнечелюстных и нижнегубных щупиках самца относится к подроду Allopsontus s. str. Среди описанных видов этого подрода только у самцов $A$. agvalensis sp.n., A. verae Kaplin, 2015 и A. hebraeus (Wygodzinsky, 1974) нижняя поверхность 5-7-го члеников нижнечелюстных и 3-го членика нижнегубных щупиков с множеством коротких щетинок, и их передние бёдра с узкими сенсорными полями из розетковидных сенсилл. Новый вид отличается от $A$. verae и A. hebraeus цветом глаз, их короткой линией контакта, небольшим количеством розетковидных сенсилл на переднем бедре, более длинным апикальным члеником нижнечелюстного щупика, более короткими грифельками на IX сегменте брюшка.

\section{Introduction}

The South Palaearctic genus Allopsontus Silvestri, 1911 includes 32 described species belonging to 8 subgenera and distributed in mountain steppes, dry steppes and semi-deserts from Armenia and Israel in the west to Mongolia and Shaanxi province in China in the east and from the Samara region and the Southern Urals in Russia in the north to Pakistan, Northern India, Tibet and Nepal in the south [Kaplin, 1993].

Four species of the genus Allopsontus were previously known from the Caucasus namely Allopsontus (Kaplinilis) abkhazicus Kaplin, 2017 (Great Caucasus, Abkhazia), A. (Allopsontus) armenicus (Mendes, 1983), A. (Allopsontinus) caucasicus (Kaplin, 1990) (Armenian Plateau, Armenia), A. (Anisoptinus) borgustani Kaplin, 2015 (northern foothills of the Great Caucasus, Kislovodsk, Russia) [Mendes, 1983; Kaplin, 1990, 2015, 2017]. Examination of the bristletails collected in Dagestan (Tsumadinsky District) has revealed a new species of this genus; its description is given below.

\section{Material and methods}

The holotype (male) was dissected and mounted on glass microscope slides in Berlese fluid. Figures were made using a microscope and a drawing projector. The ratio between the sensory field and fore femur of male were taken following the formulas of Bitsch [1964], where $\mathrm{LF}=$ length of femur, $\mathrm{WF}=$ width of femur, $\mathrm{LSF}=$ length of sensory field, WSF = width of sensory field, and $\mathrm{d}=$ distance between the border of the sensory field and base of the femur. The type of the new species is deposited in the collection of the All-Russian Institute of Plant Protection (VIZR), Russian Academy of Sciences, St. Petersburg.

How to cite this article: Kaplin V.G. 2020. A new species of bristletail of the genus Allopsontus (Microcoryphia: Machilidae) from Dagestan (Russia) // Russian Entomol. J. Vol.29. No.3. P.233-236. doi: 10.15298/rusentj.29.3.01 


\section{Results and discussion}

Family Machilidae Grassi, 1888

Subfamily Machilinae Kaplin, 1985

Genus Allopsontus Silvestri, 1911

Subgenus Allopsontus s. str., Silvestri, 1911

Type species: Machilis annandalei Silvestri, 1911

Alloposontus (Allopsontus) agvalensis Kaplin, sp.n. Figs $1-7$.

MATERIAL. Holotype, $O^{7}$ Russian Federation, Dagestan, Tsumadinsky District, near Agvali vill. leg. V. Kaplin 27. IV.2019, Andean Koisu River valley, mixed forest (Quercus, Paliurus spina-christi, Carpinus), under stones, $975 \mathrm{~m}, 42^{\circ} 32^{\prime} 20^{\prime \prime} \mathrm{N}, 46^{\circ} 07^{\prime} 27^{\prime \prime} \mathrm{E}$ (VIZR).

DESCRIPTION (holotype). Body length $9.1 \mathrm{~mm}$, width $2.1 \mathrm{~mm}$; cerci length $3.0 \mathrm{~mm}$; total eyes width $0.85 \mathrm{~mm}$, eye length $0.41 \mathrm{~mm}$; paired ocelli width and length 0.23 and 0.10 $\mathrm{mm}$, respectively; coxal styli length about $0.5 \mathrm{~mm}$. General body color (in alcohol) whitish, or light yellowish, with hypodermal pigment distributed as follows: head (excepting occiput, middle part of clypeus and labrum), mandibles, maxillae, prementum, mentum, $1^{\text {st }}-5^{\text {th }}$ palpomeres of maxillary palps, thoracic tergites and sternites, coxae, femora and tibiae, urosternites VIII and IX with purple-brown hypodermal pigment of strong and medium intensity. Labial palpi, $6^{\text {th }}$ and $7^{\text {th }}$ palpomeres of maxillary palpi and tarsi of all legs without hypodermal pigment. Scale color on surface of body brown with longitudinal darker stripe from metanotum to urotergite IX. Antennae 1.8 times shorter than body. Distal chains of flagellum divided into 5 annuli (Fig. 2). Cerci about 0.32 times body length, with one apical spike.

Compound eyes light bluish (in alcohol). Length to width ratio of compound eye 0.92 ; ratio of contact line to length of eyes about 0.16 . Paired ocelli sublateral, oval, light brown with narrow white borders. Ratios of width to length of ocelli about 2.3. Ratio of distance between inner and outer margins of ocelli to total width of compound eyes, respectively 0.41 and 0.92 (Fig. 1).

Apical palpomere of maxillary palp about 0.90 times length of preceding one; ratio of lengths of $5^{\text {th }}$ to $4^{\text {th }}$ palpomeres 1.6. Dorsal surface of $5^{\text {th }}, 6^{\text {th }}$ and $7^{\text {th }}$ palpomeres of maxillary palp with $2-3,12$ and $12-13$ hyaline spines, respectively. Underside surface of palpomeres 5-7 of maxillary palp as well as of apical palpomere 3 of labial palp with abundant small chaetae (Figs 3, 5). Apical palpomere of labial palp triangularly oval, about 1.6 times longer than wide (Fig. 3). Mandibles with 4 distal teeth (Fig. 4).

Fore femur widened. Ratios of length to width of femur, tibia and tarsus as shown in Table 1. Middle legs shorter than fore and hind legs. Ratio of length of $3^{\text {rd }}$ tarsomere to total length of tarsus $0.39-0.40$. Undersurface of tibiae and tarsi with two rows of spine-like chaetae (Fig. 6). Second tar-

Table 1. Ratios of length to width of main leg segments of the male of Allopsontus agvalensis sp.n.

Таблица 1. Отношения длины и ширины основных сегментов ног самца Allopsontus agvalensis sp.n.

\begin{tabular}{|l|c|c|c|}
\hline \multirow{2}{*}{ Segment } & \multicolumn{3}{|c|}{ Leg } \\
\cline { 2 - 4 } & Fore & Middle & Hind \\
\hline Femur & $1.61-1.67$ & $1.76-1.80$ & $1.93-1.97$ \\
\hline Tibia & $1.90-2.06$ & $1.97-2.14$ & $2.62-2.75$ \\
\hline Tarsus & $4.88-4.91$ & $4.34-4.48$ & $5.87-5.93$ \\
\hline
\end{tabular}

somere with more spine-like chaetae than the first and third tarsomeres; number of tibial spine-like chaetae increases from fore to hind tibia; fore femoral projection on underside with 14-16 thickened spine-like chaetae (Table 2). Fore femur with sensory field composed of one irregular row of 56 ramose sensilla (Fig. 6). Morphometric ratios found in the sensory field and femur as follows: LF/WF: 1.61; LSF/WSF: 2.90; LSF/LF: 0.51; WSF/WF: 0.28; d/LF: 0.41; d/LSF: $0.80 ; \mathrm{d} / \mathrm{WSF}: 2.34$. Middle and hind legs with coxal styli. Ratio of length of styli to width of coxae about 1.2-1.3. Pretarsus with bicolored lateral claws.

Urocoxites I, VI and VII with $1+1$, II-V with $2+2$ exsertile vesicles. Posterior angle of urosternites II, III $90^{\circ}$, IV and V $104^{\circ}$, VI $99^{\circ}$, VII $102^{\circ}$, VIII $139^{\circ}$. Length ratios of urosternites, urocoxites and urostyli given in Table 3.

Table 2. Number of spine-like chaetae on the tarsomeres and tibia of the male of Allopsontus agvalensis sp.n. Таблица 2. Количество игловидных щетинок на члениках лапки и голени самца Allopsontus agvalensis sp.n.

\begin{tabular}{|c|c|c|c|c|}
\hline \multirow{2}{*}{\multicolumn{2}{|c|}{ Segments }} & \multicolumn{3}{|c|}{ Leg } \\
\hline & & Fore & Middle & Hind \\
\hline \multirow{3}{*}{ Tarsomeres } & $1^{\mathrm{st}}$ & 4 & 6 & 6 \\
\hline & $2^{\text {nd }}$ & 12 & 10 & 12 \\
\hline & $3^{\text {rd }}$ & 6 & 8 & 8 \\
\hline \multicolumn{2}{|l|}{ Tibia } & $4-6$ & $12-14$ & $15-16$ \\
\hline
\end{tabular}

Table 3. Length ratios of urosternites, urostyli and urocoxites of the male of Allopsontus agvalensis sp.n.

Таблица 3. Отношения длин брюшных стернитов, грифельков и кокситов самца Allopsontus agvalensis sp.n.

\begin{tabular}{|c|c|c|c}
\hline $\begin{array}{c}\text { Abdominal } \\
\text { segment }\end{array}$ & $\begin{array}{c}\text { Urosternite: } \\
\text { urocoxite }\end{array}$ & $\begin{array}{c}\text { Urostyli } \\
\text { (not including } \\
\text { apical spines): } \\
\text { urocoxites }\end{array}$ & $\begin{array}{c}\text { Apical } \\
\text { spines: } \\
\text { urostyli }\end{array}$ \\
\hline II-IV & 0.60 & $0.57-0.58$ & $0.28-0.30$ \\
\hline V & 0.57 & 0.55 & 0.32 \\
\hline VI & 0.56 & 0.56 & 0.30 \\
\hline VII & 0.39 & 0.56 & 0.29 \\
\hline VIII & 0.36 & 0.76 & 0.25 \\
\hline IX & - & 0.82 & 0.17 \\
\hline
\end{tabular}

Table 4. Distribution of sublateral macrochaetae on urotergites and urocoxites of the male of Allopsontus agvalensis sp.n.

Таблица 4. Распределение сублатеральных макрохет на тергитах и кокситах брюшка самца Allopsontus agvalensis

\begin{tabular}{|c|c|c|}
\hline $\begin{array}{c}\text { Abdominal } \\
\text { segment }\end{array}$ & Urotergite & Urocoxite \\
\hline I & 0 & 0 \\
\hline II & $1+1$ & 0 \\
\hline III & $1+1$ & $2+2$ \\
\hline IV & $2+2$ & $1+1$ \\
\hline V & $3+3$ & $2+1$ \\
\hline VI & $5+5$ & $1+3$ \\
\hline VII & $5+5$ & $1+1$ \\
\hline VIII & $5+6$ & $1+1$ \\
\hline IX & $6+7$ & 0 \\
\hline X & $3+3$ & - \\
\hline
\end{tabular}
sp.n. 


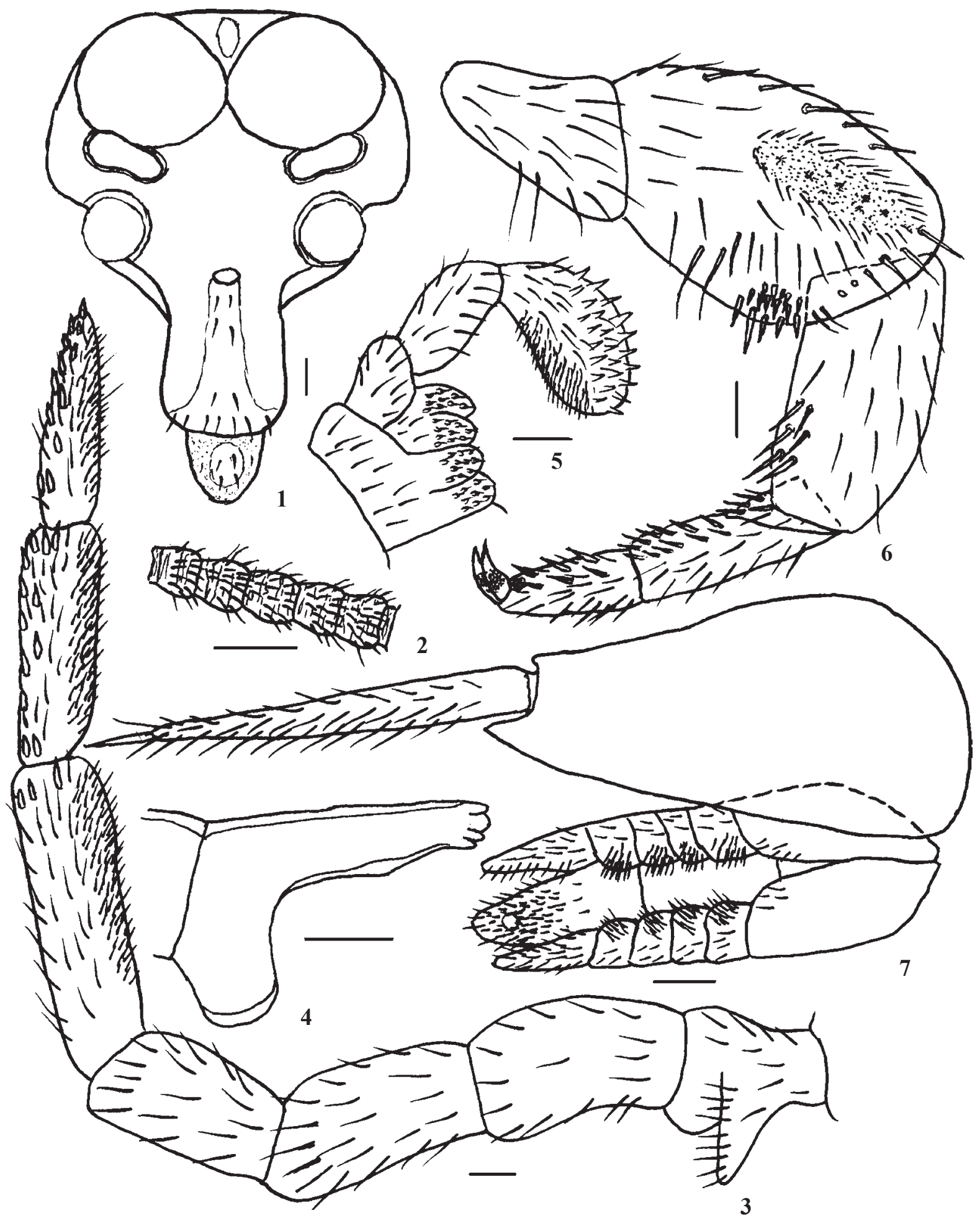

Figs 1-7. Allopsontus agvalensis sp.n., holotype (male): 1 - anterior part of head (vertex, compound eyes, paired ocelli, frons, antennae bases, median ocellus, clypeus, and labrum); 2 - distal chain of flagellum; 3 - maxillary palpus; 4 - apex of mandible; 5 - labial palpus and labium (part); 6 - fore leg (part); 7 - urocoxite IX with genital appendages. Scale bars: $0.1 \mathrm{~mm}$.

Pис. 1-7. Allopsontus agvalensis sp.n., голотип (самец): 1 - передняя часть головы (затылок, сложные глаза, парные глазки, лоб, основания усиков, медианный глазок, наличник и верхняя губа); 2 - дистальная цепочка жгутика; 3 - нижнечелюстной щупик; 4 - апикальная часть верхней челюсти; 5 - нижнегубной щупик и нижняя губа (часть); 6 - передняя нога (часть); 7 - брюшной коксит IX с половыми придатками. Масштабные линейки: 0,1 мм. 
Thoracic tergites, urotergite I, all urosternites and urocoxites I, II and IX without macrochaetae. Distribution of sublateral macrochaetae on urocoxites and urotergites given in Table 4.

Male genitalia with one pair of parameres on urite IX. Parameres with $1+5$ divisions, not quite attaining apex of penis. Penis and parameres clearly not attaining level of apex of coxites IX (Fig. 7). Length to width ratio of apical portion of penis about 2.3. Apical portion of penis 1.3 times length of basal portion.

Female unknown.

COMPARATIVE REMARKS. Allopsontus agvalensis sp.n., with $2+2$ exsertile vesicles on urocoxites II-V and without long thin chaetae on male legs, maxillary and labial palpi belongs to the subgenus Allopsontus s. str. Silvestri,
1911, including 19 species. Among these species only $A$. agvalensis sp.n., A. verae Kaplin, 2015 from South-Eastern Kazakhstan and A. hebraeus (Wygodzinsky, 1974) from Israel, have abundant small chaetae on the underside surface of palpomeres 5-7 of maxillary palp as well as of apical palpomere 3 of labial palp and the fore femur with narrow sensory field [Wygodzinsky, 1974; Kaplin, 1993, 2015] in the males only. The main differences between these species are shown in Table 5 . The new species differs from $A$. verae and $A$. hebraeus in eye color, short eyes contact line, small number of ramose sensilla in male fore femur, longer apical palpomere of the maxillary palp and shorter urostyli of urocoxites IX.

ETYMOLOGY. The new species is named after the Agvali settlement, close to where it was collected.

Table 5. Main morphological differences between males of Allopsontus agvalensis sp.n., A. verae and A. hebraeus. Таблица 5. Основные морфологические различия самцов Allopsontus agvalensis sp.n., A. verae an A. hebraeus.

\begin{tabular}{|l|c|c|c|}
\hline \multicolumn{1}{|c|}{ Morphological characters } & $\begin{array}{c}\text { Allopsontus } \\
\text { agvalensis } \\
\text { sp.n. }\end{array}$ & A. verae & A. hebraeus \\
\hline Eye color (in alcohol) & Light bluish & Black & Dark \\
\hline Ratio of length of contact line of eyes to their length & 0.16 & $0.29-0.34$ & 0.41 \\
\hline Ratio of width of paired ocelli to their length & 2.3 & $2.6-3.1$ & 2.0 \\
\hline $\begin{array}{l}\text { Ratio of lengths of apical and preceding palpomeres of } \\
\text { maxillary palp }\end{array}$ & 0.90 & $0.80-0.86$ & 0.75 \\
\hline Number of ramose sensilla in the sensory field of fore femur & $5-6$ & $8-9$ & 19 \\
\hline $\begin{array}{l}\text { Ratio of length of urostyli to urocoxites IX (not including } \\
\text { apical spines) }\end{array}$ & 0.82 & 0.94 & 0.88 \\
\hline Number of divisions of paramere & $1+5$ & $1+5$ & $1+6$ \\
\hline
\end{tabular}

Acknowledgements. I am grateful to Dr. Graeme B. Smith from Australian Museum Research Institute (Sydney, Australia) for reading and editing the English language text of this paper.

\section{References}

Bitsch J. 1964. Machilides de Sardaigne, de Corse et de l'île d'Elbe (Insecta, Thysanura) // Travaux du Laboratoire de zoologie et de la Station aquicole Grimaldi de la Faculté des sciences de Dijon. Vol.60. P.1-28.

Kaplin V.G. 1990. On the bristletail family Machilidae Thysanura from the Caucasus // Entomological Review. Vol.69. No7. P.88-93.
Kaplin V.G. 1993. Bristletails of the genus Allopsontus (Thysanura, Machilidae) of the world fauna// Entomological Review. Vol.72. No7. P.75-89.

Kaplin V.G. 2015. New species of the bristletail family Machilidae (Insecta, Microcoryphia) from the Caucasus and Southeastern Kazakhstan // Entomological Review. Vol.95. No7. P.897-917.

Kaplin V.G. 2017. New species of the bristletail family machilidae (insecta, microcoryphia) from Abkhazia // Entomological Review. Vol.97. No2. P.207-229.

Mendes L.F. 1983. Contribution à la connaissance des thysanoures (Microcoryphia et Zygentoma: Apterygota) de l'URSS asiatique // Boletim da Sociedade Portuguesa de Ciências Naturais. 2 Série. Vol.21. P.59-74.

Wygodzinsky P.W. 1974. Notes and descriptions of Machilidae from the Old World (Microcoryphia, Insecta) // American Museum Novitates. No.2555. P.1-21. 